\title{
Effect of postmortem storage on shear force value and calpain/calpastatin activity in longissimus dorsi muscle of rusa deer (cervus timorensis)
}

\author{
Orapin Jantasaeng ${ }^{1}$, Kanya Jirajaroenrat ${ }^{1,{ }^{*}}$ and Kunya Tuntivisoottikul ${ }^{2}$ \\ ${ }^{1}$ Department of Animal Production Technology and Fishery, Faculty of Agricultural Technology, King Mongkut's Institute of \\ Technology Ladkrabang, Bangkok, Thailand \\ ${ }^{2}$ Department of Agricultural Education, Faculty of Industrial Education and Technology, King Mongkut's Institute of Technology \\ Ladkrabang, Bangkok, Thailand
}

\begin{abstract}
The objective of this study was to determine the effects of aging period on shear force values and activities of calpain/calpastatin enzymes of the longissimus dorsi (LD) muscle from rusa deer (Cervus timorensis). The shear force values were measured with instron materials testing machine. Results showed that postmortem storage influenced meat tenderness with a highly significant reduction of shear force value from $9.01 \pm 0.83 \mathrm{~kg} / \mathrm{cm}^{2}$ at day 1 to $4.34 \pm 0.10 \mathrm{~kg} / \mathrm{cm}^{2}$ at day $21(\mathrm{P}<0.01)$. Determination of the enzyme activities indicated that the $\mu$-calpain activity decreased significantly from $1.50 \pm 0.42$ to $0.19 \pm 0.28$ units/g of meat $(\mathrm{P}<0.01)$, whereas m-calpain activity $(22.88 \pm 9.64$ to $16.95 \pm 8.34$ units $/ \mathrm{g}$ of meat $)$ and calpastatin activity $(9.93 \pm 2.37$ to $6.82 \pm 2.96$ units/g of meat) slightly decreased $(\mathrm{P}>0.05)$. Shear force values were significant correlated with higher levels of $\mu$-calpain $(\mathrm{r}=0.915)$ and $\mathrm{m}$-calpain $(\mathrm{r}=0.758)$, respectively. However, the values were not significant related to the calpastatin activity $(r=0.462)$. Therefore, this study confirmed that in the case of rusa deer, $\mu$-calpain is a key factor controlling postmortem meat tenderness compared to $\mathrm{m}$-calpain and calpastatin. The results suggested that storage of the rusa deer meat for 7 days is enough to achieve aging of the LD muscle, which may help to reduce the cost of meat production.
\end{abstract}

Keywords: postmortem storage, shear force, calpain/calpastatin activity, rusa deer.

\section{Introduction}

Rusa deer (cervus timorensis) have been an alternative farm animal. Most important commercial product in the tropical countries is deer meat [1]. Deer meat contents a high level in protein and minerals, but low-fat content and cholesterol [2-3]. In Thailand, consumption of deer meat is increased. Improvement of farm management, feeding and reproduction were studied, but improvement of the deer meat quality is uninformative. In meat quality traits, tenderness is commonly known as one of the most important traits for consumer. Tenderness is controlled by the level of proteolysis of the endogenous proteolytic enzymes of the calpain protease system including calpains and calpastatin [4-7]. The calpains are cysteine peptidases present in different forms and tissues while the calpastatin acts as a specific inhibitor. Activities of the calpains is mainly controlled by $\mathrm{Ca}^{2+}$, phospholipids and their specific inhibitor. Several studies reported that the calpain concentration in the muscle and the calpain/calpastatin ratio could be used as a good predictor of ultimate tenderness. The influences of the calpain enzyme system on meat tenderness can be expected to apply in deer meat $[4-5,8]$. However, studies on the meat tenderization of rusa deer has been limited in Thailand. Here, the shear force values, and the $\mu$-calpain, m-calpain and calpastatin in the longissimus dorsi muscle of the rusa deer associated with postmortem storage were revealed.

\section{Material and Methods}

\subsection{Samples Preparation}

The rusa deer meat was raised by Deer Co-operative of Thailand LTD., Kasetsart University, Kamphaeng Saen Campus Thailand. Ten female rusa deer (2 to 3 years of age, live weight 40 to $60 \mathrm{~kg}$ ) were slaughtered and longissimus dorsi (LD) muscle were obtained within 45 min after exsanguination. The LD muscles were removed from the left side of the carcass, wrapped in plastic wrap, placed in cooling pack and transported immediately to meat science laboratory at Meat Technology Research Network Center, King Mongkut's Institute of Technology Ladkrabang, Bangkok, Thailand. The LD muscles were trimmed free from external fat and connective tissue. After that, LD muscles were divided into six pieces and vacuum packed. All was aged at $4{ }^{\circ} \mathrm{C}$ for $1,3,5,7,14$ and 21 days postmortem.

\subsection{Shear Force Values Measurement}

The LD muscles were chopped into $2.5 \mathrm{~cm}$ thick, were boiled on water bath at $80^{\circ} \mathrm{C}$ until reached an internal

\footnotetext{
${ }^{*}$ Corresponding author: kanyatran@gmail.com
} 
temperature of 70 to $75^{\circ} \mathrm{C}$. The sample was cooled by rinsing with water until the internal temperature decreased to $25^{\circ} \mathrm{C}$. They were chopped into $1 \mathrm{~cm}$ in diameter parallel to the longitudinal orientation of the muscle fibers. Theshear force values were measured by instron materials testing machine (Instron Model 1011, USA). The average maximum force $\left(\mathrm{kg} / \mathrm{cm}^{2}\right)$ to cut across the fibers. Ten pieces was used for each sample [9].

\subsection{Calpain/Calpastatin Activity Analysis}

Ten grams of LD muscles was homogenized in $30 \mathrm{~mL}$ of extraction buffer $(100 \mathrm{mM}$ Tris/HCl, $\mathrm{pH} 8.3,10 \mathrm{mM}$ EDTA,.05\% [vol/vol] MCE, $100 \mathrm{mg} / \mathrm{L}$ ovomucoid, 2 $\mathrm{mM}$ phenylmethylsulfonyl fluoride (PMSF), $6 \mathrm{mg} / \mathrm{L}$ leupeptin, $4^{\circ} \mathrm{C}$ ) at 30 second cooling period between bursts. The homogenate was centrifuged at $30,000 \times \mathrm{g}$ max for 1 hour at $4^{\circ} \mathrm{C}$ and filtered through glass wool. After clarification, the sample were dialyzed against 25 volumes of dialysis buffer $(40 \mathrm{mM}$ Tris/ $\mathrm{HCl}, \mathrm{pH} 7.35,5$ $\mathrm{mM}$ EDTA,.05\% [vol/vol] MCE) for 24 hours at $4{ }^{\circ} \mathrm{C}$ and centrifuged $30,000 \times \mathrm{g}$ max for 30 minutes at $4^{\circ} \mathrm{C}$. The extract applied to a DEAE-Sephacel by gravity. After loading, the column was washed with 5 column volumes of elution buffer $(40 \mathrm{mM}$ Tris/ $\mathrm{HCl}, \mathrm{pH} 7.35$, $0.5 \mathrm{mM}$ EDTA, $0.05 \%$ [v/v] MCE) to removed unbound proteins. The $\mu$-calpain and calpastatin were eluted with $80 \mathrm{ml}$ of $200 \mathrm{mM} \mathrm{NaCl}$ elution buffer, the m-calpain was subsequently eluted with $80 \mathrm{ml}$ of $400 \mathrm{mM} \mathrm{NaCl}$ elution buffer. The eluted was collected $2 \mathrm{~mL} /$ fractions and measured at A280 nm and then the fraction consisted of protein were pooled for analysis of the calpains system activity. One unit of calpastatin activity was defined as the amount of the inhibitor that inhibits one unit of $\mathrm{m}$ calpain activity. One unit of $\mu$-calpain and m-calpain activity was defined as the amount of enzyme that catalysed an increase of 1.0 absorbance until at A280 nm [10].

\subsection{Statistical Analysis}

Completely Randomized Design (CRD) was used to design the experiment. Independent variable was aging period with separated into 6 levels $(1,3,5,7,14$, and 21 days). Shear force values, and $\mu$-calpain, m-calpain and calpastatin activities were dependent variables. Ducan's New Multiple Range Test was used to compare the difference of means. The Pearson Correlation between the shear force value and the enzyme activities was also analysed.

\section{Results and discussions}

\subsection{Shear Force Values}

The shear force values decreased dramatically from day 1 to 7 postmortem aging from $9.01 \pm 0.83 \mathrm{~kg} / \mathrm{cm}^{2}$ to $6.47 \pm 1.12 \mathrm{~kg} / \mathrm{cm}^{2}(\mathrm{p}<0.01)$ and then declined slowly to
$4.34 \pm 0.10 \mathrm{~kg} / \mathrm{cm}^{2}$ after 21 days of aging $(\mathrm{P}<0.01)$, as shown in Table 1.

Table 1. Mean $\pm \mathrm{SD}$ of shear force value $\left(\mathrm{kg} / \mathrm{cm}^{2}\right)$ during aging period

\begin{tabular}{cc}
\hline Aging period (day) & Shear force values $\left(\mathrm{kg} / \mathrm{cm}^{2}\right)$ \\
\hline 1 & $9.01 \pm 0.83^{\mathrm{a}}$ \\
3 & $8.20 \pm 0.63^{\mathrm{ab}}$ \\
5 & $6.92 \pm 0.67^{\mathrm{bc}}$ \\
7 & $6.47 \pm 1.12^{\mathrm{bc}}$ \\
14 & $5.12 \pm 0.88^{\mathrm{dc}}$ \\
21 & $4.34 \pm 0.10^{\mathrm{d}}$ \\
\hline
\end{tabular}

a,b,c Different superscripts showed highly significant differences $(\mathrm{P}<0.01)$

After 3 days of aging, the shear force value was 8.20 $\mathrm{kg} / \mathrm{cm} 2$, however, the values could be varied between 2.1 to $4.9 \mathrm{~kg} / \mathrm{cm} 2$ [6]. In this study, the longer aging period decreased shear force values in agreement with the previous report found in the loin muscle of red deer (Cervus elaphus $) \quad(\mathrm{P}<0.001) \quad$ [11]. Likewise, the tenderness of loin muscle of red deer was improved after 21 days of aging [12].

\subsection{Calpain/calpastatin activities}

After calpain analysis, the results showed that the $\mu$ calpain activity decreased significantly from $1.50 \pm 0.42$ to $0.19 \pm 0.28$ units $/ \mathrm{g}$ of meat $(\mathrm{P}<0.01)$, whereas mcalpain activity deceased slightly from $22.88 \pm 9.64$ to $16.95 \pm 8.34$ units/g of meat and calpastatin activity decreased slightly from $9.93 \pm 2.37$ to $6.82 \pm 2.96$ units/g of meat $(\mathrm{P}>0.05)$ during aging period, as present in the Table 2.

Table 2. Mean \pm SD of $\mu$-calpain, m-calpain and calpastatin activities (units/g of meat) during aging period

\begin{tabular}{clll}
\hline $\begin{array}{c}\text { Aging } \\
\text { period } \\
\text { (day) }\end{array}$ & $\mu$-calpain & m-calpain & calpastatin \\
\hline 1 & $1.50 \pm 0.42^{\mathrm{a}}$ & $22.88 \pm 9.64$ & $9.93 \pm 2.37$ \\
3 & $1.05 \pm 0.54^{\mathrm{ab}}$ & $21.10 \pm 8.57$ & $9.29 \pm 2.10$ \\
5 & $0.74 \pm 0.47^{\mathrm{ab}}$ & $20.19 \pm 8.94$ & $8.96 \pm 1.99$ \\
7 & $0.60 \pm 0.46^{\mathrm{bc}}$ & $20.02 \pm 8.95$ & $7.59 \pm 2.60$ \\
14 & $0.46 \pm 0.33^{\mathrm{bc}}$ & $18.68 \pm 8.72$ & $7.18 \pm 3.00$ \\
21 & $0.19 \pm 0.28^{\mathrm{c}}$ & $16.95 \pm 8.34$ & $6.82 \pm 2.96$ \\
\hline
\end{tabular}

a,b,c Different superscripts in column show highly significant differences $(\mathrm{P}<0.01)$

In this study, $\mu$-calpain activity decreased significantly during aging time. The result agreed with previous study which found that the $\mu$-calpain activity was gradual decline $(\mathrm{P}<0.05)$ after 1 and 3 days postmortem, and after 15 days postmortem $\mu$-calpain activity was not detected $(\mathrm{P}>0.05)$ [17]. At the same time, $\mu$-calpain was activated and then they activity lost though an autolytic process [6]. Similarity to the change of calpain/calpastatin activity in beef, the activity of $\mu$ calpain decreased rapidly during postmortem aging but activity of m-calpain activity changed slightly during the first 7 day, whereas calpastatin activity decreased substantially during this period [18]. 


\subsection{Correlation of shear force values and Calpain/calpastatin activities}

The correlation between shear force values and $\mu$ calpain, m-calpain and calpastatin activities (Table 3.) shows some interesting among the analysis variables. Shear force value was significantly correlated with higher levels of $\mu$-calpain activity $(\mathrm{r}=0.915)$ and $\mathrm{m}$ calpains activity $(\mathrm{r}=0.758)$, respectively. However, the value was not significantly related to calpastatin activity $(\mathrm{r}=0.462)$. The activities of m-calpains and $\mu$-calpain had highly significantly related $(r=0.632)$. Furthermore, both had significantly correlated with calpastatin activity $(\mathrm{r}=0.852)$. These results summarized that there was the correlation between shear force value, $\mu$-calpain, and $\mathrm{m}$ calpain activities $(\mathrm{P}<0.01)$, but not calpastatin activity. There were reported that the postmortem storage and processing affect the meat tenderness [13], and the most of postmortem tenderness improvement is attributed to $\mu$-calpain [14], because after aging storage, the myofibrillar proteins were degraded by calpain system enzyme. They broke muscle protein by autolysis, thus, the resulting in the degradation of myofibrillar proteins and therefore improved tenderness [15-16]. These findings are consistent with previous reports as it showed that a strong correlation between the calpain and meat tenderization postmortem [19]. However, some reported that there was the good correlation between calpastatin activity and shear force in fallow deer meat [20]. The rate of tenderization indicates that the calpain and calpastatin system are closely linked to the proteolytic breakdown of myofibrillar proteins [21].

Table 3. Pearson's correlation coefficients between shear force and $\mu$-calpain, m-calpan and calpastatin

\begin{tabular}{cccc}
\hline & $\mu$-calpain & m-calpain & calpastatin \\
\hline Shear force & $0.915^{* *}$ & $0.758^{* *}$ & $0.462^{\text {ns }}$ \\
$\mu$-calpain & & $0.632^{* *}$ & $0.745^{* *}$ \\
m-calpain & & & $0.852^{* *}$ \\
\hline
\end{tabular}

${ }^{\text {ns }}$ non significant difference $(\mathrm{P}>0.05)$, and ${ }^{* *} \mathrm{P}<0.01$

In conclusion, this study confirms that in the case of rusa deer, $\mu$-calpain plays a key factor controlling postmortem meat tenderness compared to m-calpain and calpastatin. We suggest that postmortem storage should not exceed 7 days is enough to achieve aging of the LD muscle, which may help to reduce the cost of meat production.

Financial support for this work was provided by the Graduate Studies, King Mongkut's Institute of Technology Ladkrabang, Bangkok, Thailand and the Center of Excellence on Agricultural Biotechnology, Science and Technology Postgraduate Education and Research Development Office, Commission on Higher Education, Ministry of Education (AGBIO/PERDO-CHE), Bangkok, Thailand.

\section{References}

1. R. Sookhareea, K.B. Woodford, G. McL. Dryden, Asian-Australas J Anim Sci, 14 (2001)
2. H.T. Shin, R.J. Hudson, X.H. Gao, J.M. Suttie, Asian-Aust. J Anim Sci, 13 (2000)

3. L.C. Hoffman, E., Wiklund. Meat Sci. 74(2006)

4. M. Koohmaraie, Meat Sci, 43 (1996)

5. M.A. Sentandreu, G. Coulis, A. Ouali, Trends Food Sci. Technol, 13(2002)

6. E. Wiklund, V.M.H. Barnier, F.J.M. Smulderd, K. Lundstriim, Meat Sci, 46 (1997)

7. E. Dransfield, Meat Sci, 36 (1994)

8. D.E. Goll, V.F Thompson, H. Li, W. Wei, J. Cong, Physiol. Rev, 83 (2003)

9. E.F. Delgado, G.H. Geesink, J.A. Marchello, D.E. Goll, M. Koohmaraie, J Anim Sci, 79 (2001)

10. G.H. Geesink, M. Koohmaraie, J. Anim Sci, 77 (1999)

11. E. Wiklund, J.M. Stevenson-Barry, S.J. Duncan, R.P. Littlejohn, Meat Sci, 59 (2001)

12. E. Wiklund, P. Dobbie, A. Stuart, R.P. Littlejohn, Meat Sci, 86 (2010)

13. N. Perry, Int. J. Gastron, Food Sci, 1 (2012)

14. M.J. Colle, J.A. Nasados, J.M. Rogers, D.M. Kerby, M.M. Colle, J.B. Van Buren,R.P. Richard, G.K. Murdoch, C.J. Williams, M.E. Doumit, Meat Sci, 135 (2018)

15. D. E. Goll, R. G. Taylor, J. A. Christiansen, V. F Thompson, Proceedings of the Reciprocal Meat Conference, 44 (1991)

16. M.I. Khan, S. Jung, K.C. Nam, C. Jo, Korean J. Food Sci An, 36 (2016)

17. E. Veiseth, S.D. Shackelford, T.L. Wheeler, M. Koohmaraie, J Anim Sci, 79 (2001)

18. M.L. Boehm, T.L. Kendall, V.F. Thompson, D.E. Gol, J Anim Sci, 76 (1998)

19. M. Koohmaraie, G.H. Geesink, Meat Sci, 74 (2006)

20. L.A. Volpelli, S. Failla, A. Sepulcri, E. Piasentier, Meat Sci, 69 (2005)

21. J.D. Morton, R. Bickerstaffe, M.P. Kent, E. Dransfield, G.M Keeley, Meat Sci, 52 (1999) 